\title{
Importance, Utilization and Health of Urban Forests: A Review
}

\author{
Alexandra D. SOLOMOU ${ }^{1 *}$, Eleni T. TOPALIDOU ${ }^{2}$, Rafaelia GERMANI ${ }^{3}$, \\ Apostolia ARGIRI ${ }^{3}$, George KARETSOS ${ }^{1}$ \\ ${ }^{1}$ Institute of Mediterranean and Forest Ecosystems, Hellenic Agricultural Organization "Demeter", N. Chlorou 1, 11528, Athens, \\ Greece; alexansolomou@gmail.com (*correspondingauthor); gekaretsos@yahoo.gr \\ ${ }_{2}^{2}$ Institute of Forest Research, Hellenic Agricultural Organization "Demeter”, Vasilika, 57006, Thessaloniki, Greece; elenitopalidou@gmail.com \\ ${ }^{3}$ University of Thessaly, Department of Agriculture, Crop Production and Rural Environment, Fytokou Str., N. Ionia, 38446, Volos, \\ Greece; rafgermani@hotmail.gr; argyriapog@yahoo.gr
}

\begin{abstract}
Urbanization and development of cities are rapidly increasing across the world and urban forests constitute important tools that maintain the basic environmental and ecological functions of cities on which plant, animal and human existence depend. This paper presents a literature review on importance, utilization and health of urban forests that are important in providing ecosystem services for the sustainability of cities. Analysis of the literature from the main academic resources databases indicates that urban forest is a dynamic system which includes trees, shrubs, green space, soil and water that supports them. Urban forests provide many functions, services and benefits which are needed for the sustainable development of urban areas. In addition, health and appearance of trees' composition are the most important factors in determining a city's visual image and quality of life. Thus, urban forests are an important component of an ecosystem in any community development. Furthermore, management of urban forests can increase their potentials and therefore their functions, services and benefits. Green infrastructure and ecosystem services are the most efficient tools that cities can utilise to remain healthy, robust and liveable. Hence, the planners, architects, engineers, foresters, agriculturists and all those involved in decision making should be utilized the present literature review and incorporate the concept of urban forest in their plans and programs so as to achieve the sustainability of cities.
\end{abstract}

Keywords: benefits; ecosystem; environment; functions; services; urban areas

\section{Introduction}

Cities are emerging as the most threatened by climate change, and as the first responders to it (Rosenzweig et al., 2011). Understanding the impacts of climate change on the urban environment will become even more important, with increasing urbanization (UN-Habitat, 2011). Temperatures have already risen in cities around the world due to both climate change and the urban heat island effect (Rosenzweig et al., 2018).

It is noteworthy that urban forestry plays an important role in the urban environment. Urban forest is a complex ecosystem, closely related to the urban ecosystem (Christopoulou et al., 2007). It has been recognized as the forest and forest-like vegetation in and peripheral urban environment that appear in different composition. They can be found in free spaces, parks and gardens, in streams and in forest stands (Patarkalashvili, 2017). Health and environmental benefits of urban forests, which range from protecting and maintaining biodiversity to helping in the mitigation/adaptation of climate change, cannot be overlooked (Molla, 2015).

Several recent studies have focused on various aspects of urban forest research: cultural ecosystem benefits from urban and periurban green infrastructure (O'Brien et al., 2017), partnerships in urban forestry (Hansmann et al., 2016), human-environment interactions (Kabisch et al., 2015), the role of urban green space to urban residents (Rupprecht and Byrne, 2014), empirical evidence of the benefits of urban parks (Konijnendijk et al., 2013), urban tree benefits, costs and assessment methods in different climatic zones (Roy et al., 2012), vegetation affects the improvement of microclimatic conditions in urban areas (Georgi and Dimitriou, 2010), nutrient cycling and foliar status in an urban pine forest (Michopoulos et al., 2007), promoting and preserving biodiversity in urban green spaces (Solomou et al., 2014). Although these studies have led to a better understanding of the urban forest functions, 
utilization and health of urban forests have been scarcely studied. Hence, this paper describes and discusses the importance, utilization and health of urban forests that are important in providing multifunctional urban green areas that will contribute to the sustainability of cities.

\section{Literature review}

Literature review is a thorough fathom into the already existing knowledge with regard to a topic selected by researchers (Botelho et al., 2011). It serves as a basis to build further knowledge and (at the same time) avoid repetition of work already been done by others. The literature search relevant to the importance, utilization and health of urban forests was decided to take into consideration the period of the past 35 years with particular emphasis in recent literature (from year 2000 to 2018). The information was obtained from the main online scientific sites including ScienceDirect, SciFinder, PubMed, Google Scholar and Scopus. Searches were also undertaken in the Institute of Mediterranean and Forest Ecosystems, and University of Thessaly library, dissertation and thesis search engines like ProQuest, Open-thesis and National Documentation Centre. The keywords used in the search included "importance", "utilization", "health", "benefit", "urban forest", "urban ecosystem service" etc. (Fig. 1).

The literature sources included papers published in international journals, books and websites. Full papers were downloaded when possible. In cases when it was not possible to download full papers, titles of those papers were googled and downloaded from other publication databases including personal profiles of researchers from social networking sites such as Research Gate and Academia.edu.

\section{Urban forest ecosystem services}

Urban forests provide a significant number of goods and services. The ecosystem services provided by green spaces depend on their physical qualities and functions, and they

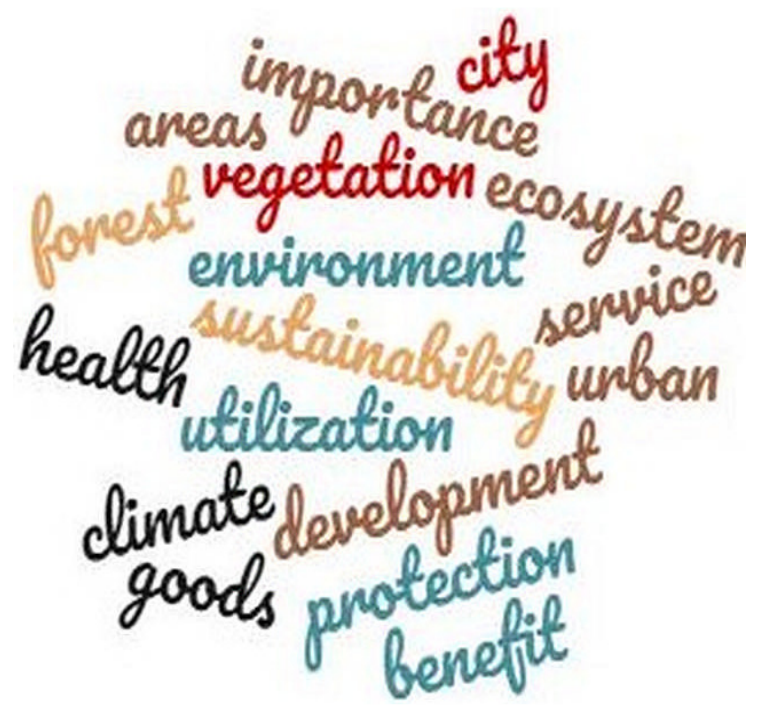

Fig. 1. Word Cloud of key-words that it has been used in the scientific sites. Source: Prepared by the authors using https://www.wordclouds.com/ provide values for the human community (Haines-Young and Potschin, 2008). According to Millennium Ecosystem Assessment (MEA, 2005), ecosystem services-values of the environment are divided into four main categories: a) Provisioning services (food, water, fibre etc.); b) Regulating services (climate and water regulation, pollination etc.); c) Cultural services (recreation, education etc.); d) Supporting services (nutrient cycling etc.) (Fig. 2). We need a thorough understanding of urban ecosystem services so as to be able to acquire a better implementation and a more fruitful planning process. Urban forests are very important and their beneficial qualities depend on how well the concerned services carry out their obligations towards the city (Jansson, 2014).

\section{Importance and utilization of urban forests}

Urban green areas are a symbol of nature and life in the often harsh city environment. The provision of urban green spaces and their associated benefits are important for sustainable urban development as far as ecological, economic and social aspects are concerned (Jansson, 2014) and are considered «a key ingredient for city sustainability» (Chiesura, 2004). Most studies have investigated ecosystem services with reference to humans (Tallis and Polasky, 2009) as they emphasize on health and social benefits and services. An active lifestyle with regular physical activity, supported by having green spaces accessible from home, diminishes the risk of dying from severe diseases such as a number of cancer forms (Zoeller, 2009). Their social benefits include a decrease in psychological stresses, quick recovery of patients and a sense of well-being (Akbar et al., 2014). However, the regular assumption in the literature is that trees in general act as pollution removal and thus are desirable. Nevertheless, we have to bring the ecological perspective out on this issue.

Air filtration, microclimate regulation, $\mathrm{CO}_{2}$ reduction, preservation of biodiversity and reduction of global warming are some of the main ecological benefits that have been analysed in this review.

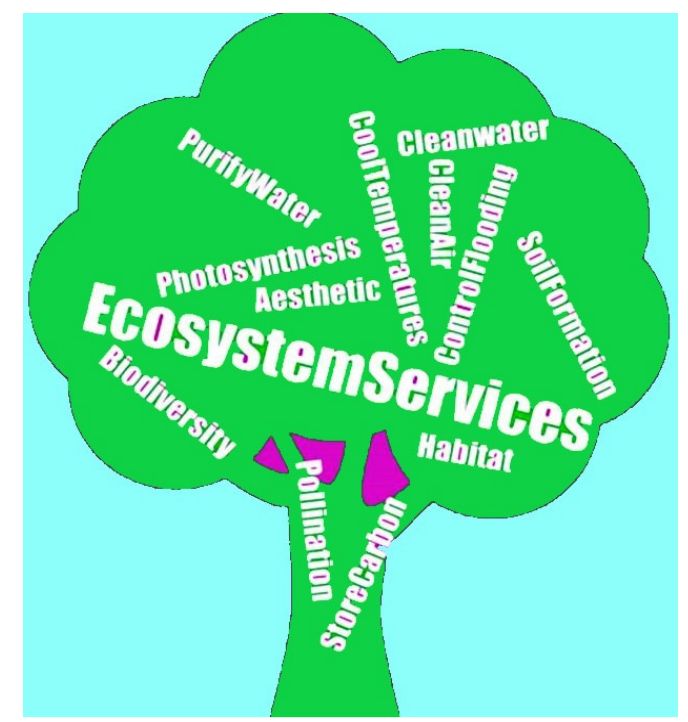

Fig. 2. Ecosystem services-values of the environment. Source: Prepared by the authors using https://www.wordclouds.com/ 
12

According to the literature, green space density as the relative tree cover affects the relationship between green space and the mitigation of air pollution (Doick et al., 2014). Tree canopies are an important sink for gaseous pollutants such as ammonia, nitrogen and sulphur oxides. Gaseous pollutants and particles trapped in tree canopies constitute the dry deposition and can be removed by rain ending up in the forest floor of urban forests as throughfall. Thus, in comparison to remote areas' forests, the concentrations of pollutants in throughfall in urban forests are high (Bolund and Hunhammar, 1999). Chiwa et al. (2003) found that throughfall fluxes of $\mathrm{N}$ and $\mathrm{S}$ in an urban pine forest in Hiroshima were so high that they affected plant health. According to Nowak (1994), after filtering the air pollutant particles, urban forests act as passive sinks for particulate matter and as Sæbø et al. (2017) mentions, the rates of the particulate matter accumulation have been recorded at $10-70 \mu \mathrm{g} \mathrm{per} \mathrm{cm}^{2}$ of leaf area. Furthermore, it is stated that, diversity of tree species of evergreen, conifer and deciduous tree species has complementary air-pollution uptake patterns and provide maximum air-quality improvements (Rowe, 2011).

Another important benefit of urban forests is the $\mathrm{CO}_{2}$ removal from the atmosphere through photosynthesis, and in this way decreasing the consumption of fuel for heating and cooling by providing shade and insulation (Ferrini and Fini, 2010). Also, trees in urban green infrastructure capture and sequester carbon mitigating the negative effects of emissions. Carbon sequestration is the removal of the greenhouse gas carbon dioxide and its incorporation into plants. Any green spaces balance carbon taking more than returning to the atmosphere (Nowak, 2013; Jose, 2018). Thus, a forest in a green space maximizes carbon sequestration (Wolf, 2010).

According to Dimoudi and Nikolopoulou (2003), vegetation in the urban environment can greatly improve the urban microclimate, as well as mitigate the heat island effect, by reducing summer air temperatures. This effect is noticed not only within the boundaries of the green area, but it also extends beyond the park itself, particularly affecting the leeward side of it. Therefore, increasing vegetation in the urban context can be an effective way of mitigating the heat island (UHI), and benefit urban centres (Georgi and Dimitriou, 2010). Trees and green spaces contribute considerably not only to the improvement of urban climate, but also to the UHI mitigation. Decrease in the temperature is achieved through trees that provide solar protection, affect air movements and heat exchange, absorb solar radiation and cool the air through evapotranspiration processes. It should be noted that urban parks may extend their cooling potential and decrease ambient temperatures in adjacent urban zones depending on the thermal balance of the overall area under study (Cohen et al., 2013).

As a matter of fact, adequate amount of green spaces of pertinent quality in cities may actually allow the presence of specialized forest species in urban landscape (Mörtberg and Wallentinus, 2000). In a study which occurred in Örebro, Sweden, the bird richness was examined in four strata such as: City centre, Residential, Greenway and Periphery, in order to evaluate the functionality of different types of urban green spaces as far as diversity is concerned. As
Angelstam et al. (2004) mentions, birds are mobile organisms which depending on the species demand the existence of a large diversity of habitat at different spatial scales. It was demonstrated that periphery which held the most complex vegetation, seemed to have the highest number of bird species (hole-nesters, woodpeckers, forest birds and urban birds). Furthermore, it is important to mention that "characteristics of the vegetation structure are important factors for birds recognizing their environment in urban areas" (Fernandez-Juricic, 2004). Also, Plexida et al. (2014) recorded in their study in Greece 96 plant species, from 77 genera and 38 families. More specific, the results of this study showed that only $41.6 \%$ of trees were Greek native species and $58.4 \%$ were exotic. Moreover, Cornelis and Hermy (2004) revealed in their survey in Flanders, that the 15 parks which were examined contained about 30\%, $50 \%, 40 \%$ and $60 \%$ of the total number of wild plant species, breeding birds, butterflies, and amphibians respectively. Urban forests seem to shelter endangered species and species of high conservation value. It is a matter of fact that, endangered species in Sweden (identified on the Red List of Swedish species) find home in urban green areas. According to Colding et al. (2003) the densely populated Stockholm contains two-thirds of red-listed species and as far as endangered plant species are concerned, Dryopteris cristata L. and Buxbaumia viridis (Moug.) Moug \& Nestl. were observed in Roslangen, Stockholm country (Gustafsson, 2002).

\section{Urban forest health}

In forestry, up until recently, tree health was mainly related to the factors affecting tree production (wood and non-wood products). In contrast to urban forestry, tree health has always been of important consideration since the overall good visual tree appearance is one of the traits which is highly valued (Magasi, 1995).

Urban trees are usually planted in locations which are not ideal for their growth (e.g. roadsides, city parks, recreation areas etc.) and as such they are predisposed to vigor-related diseases (Tattar, 1989). Trees in urban areas are subjected to many adverse stress factors and their impact on tree health is highly influenced by factors such as tree susceptibility to the various stresses, the type, the severity and the stress duration, the age and the initial health condition (vigor) of the tree (Fraedrich, 2009). Diseases of most urban trees can be categorized into two broad categories: (a) infectious and (b) non-infectious diseases. Infectious diseases are caused by microorganisms such as fungi, bacteria, nematodes, viruses and mycoplasmas, whereas non-infectious diseases are caused by environmental or meteorological stresses such as environmental stresses, human activities, animal injury (Phillips and Burdekin, 1982). In urban areas trees are exposed to high levels of air, water and soil pollution, soil compaction or inadequate room for root expansion, pruning woods etc. (Paap, 2017). Such stresses Often predispose trees to infections by secondary biotic pests (insects and diseases) (Himelick, 1997). The survival and the vigor of the trees are determined by the total effects of the stress factors that the trees are exposed to and the timespan of the stress factors (Magasi, 1995). 
Accurate diagnosis of the problem is often difficult because many factors should be considered and assessed in order to estimate the actual cause or causes of the problem (Fraedrich, 2009). Detection of the causal agent is often difficult because similar symptoms are caused by various disorders and it is not always easy to specify if the observed disorders are attributed to infectious (pathogen infection) or non-infectious diseases (environmental, soil nutrient deficiencies, cultural, site disorders etc.) (Magasi, 1995; Fraedrich, 2009); often a combination of many disciplines related to tree health (e.g. botany, plant pathology, plant physiology, soil microbiology etc.) is required in order to identify precisely the causal agent (Tattar, 1989). Moreover, many pathogens exhibit prolonged lag times between the infection and the development of the visual symptoms and therefore, detection and diagnosis of the causal agent is rather difficult (Tomlinson, 2015).

\section{Non-infectious diseases}

Non-infectious diseases are caused by nonliving factors and they cannot spread from plant to plant. Nonliving factors related to environmental, cultural and site disorders can adversely affect plant health and the growth of the trees (Sturrock, 2011). Common abiotic disorders include temperature extremes, soil moisture extremes, wind, soil disorders (nutrient deficiencies, adverse $\mathrm{pH}$, drainage, contaminants etc.), chemicals (agrochemicals, air and soil pollutants etc.), mechanical injuries (wounds, storm damage, construction injuries, animal injuries, transplanting etc.), improper cultural practices (improper pruning, planting depth etc.) (Phillips and Burdekin, 1982; Sturrock, 2011). Symptoms of non-infectious diseases usually appear uniformly on the entire tree and they may affect all trees of the same species in a specific area. Common symptoms of non-infectious diseases include sunscalds, leaf scorch, interveinal necrosis, drought cracks, dieback of twigs and small branches (usually at the upper crown), chlorosis of the lower leaves, wilting, partial or total decline of the tree (Tainter and Baker, 1996). The best diagnostic criteria for noninfectious diseases are: (a) the lack of any evidence of living pathogens and (b) the regularity of symptom expression on the trees (Tattar, 1989).

\section{Infectious diseases}

Infectious diseases include most of the well-known disease problems caused by fungi, bacteria, viruses and mycoplasmas. The diseases can be categorized according to the type of the pathogen that causes the disease or according to the part of the tree that is affected (leaves, stem, bark, roots) (Tattar, 1989). In this review, we will discuss the diseases of urban trees categorized according to the part of the tree that is affected, since the description of each disease separately is beyond the scope of this review.

\section{(a) Leaf and needle diseases}

Leaf or foliar diseases are a common problem for most species of landscape trees and shrubs (Beckerman, 2014). Foliar pathogens usually have a life cycle with an anamorphic stage which is produced during the growing season (asexual stage) and the perfect stage (sexual stage) which is formed at the end of the growing season, usually on shed or leaves; indeed some of them have complicated life cycles and require two hosts to complete their life cycles (e.g. rusts) (Kehr, 2016). Due to foliage diseases, chlorophyll is destroyed and various degrees of unsightly appearance is developed at several plant parts (Magasi, 1995). The most common and conspicuous symptoms which appear on the leaves of the trees are small or more extended spots, blotches, blights, blisters or curls, galls or irregular necroses (Beckerman, 2014; Kehr, 2016). When it comes to needle infection, symptoms are described as needle blight, needle cast, brown spot etc. (Beckerman, 2014; Kehr, 2016). Some of the most common and damaging foliage diseases of urban trees and shrubs include: (i) anthracnose (caused by the genus Gnomonia) (Beckerman, 2014; Kehr, 2016); (ii) scab (caused by Venturia spp.) (Tattar, 1989); (iii) powdery mildews which include hundreds of different powdery mildews species that most of them are fairly host specific (Olsen, 1999; Beckerman, 2014); (iv) tar spot (caused by Rhytisma spp.) (Tattar, 1989); (v) needle cast disease of pines (caused by Lophodermium spp.) (Ziller and Hunt, 1977); (vi) Dothistroma needle blight (previously referred to as Red Band Needle Blight) of pines (caused by Dothistroma pini and Dothistroma septosporum) (Barnes et al., 2008; Kehr, 2016; Woods et al., 2016); (vii) rust diseases (caused by numerous fungal species) (Olsen, 1999; Beckerman, 2014).

\section{(b) Shoot, stem and trunk diseases}

Shoot, stem and trunk diseases are usually associated with either the formation of cankers which may considerably vary in size and in shape (Tattar, 1989) or with disturbance of the vascular tissue by plugging up the water and nutrient movement in the tree (Magasi, 1995). Most of the fungi that cause this type of disease are facultative parasites which invade in healthy trees through physical openings (e.g. branch stumps) or wounds (mechanical injuries) (Tattar, 1989). The pathogens affect the barkcambium tissues; they weaken the physical strength of the affected tree parts and often cause the death of the affected tissues (Magasi, 1995). Although dead or decayed wood has a wide range of ecological values in forest ecosystems, it is not considered acceptable in urban environments due to the high risk of causing harm to people (Annesi et al., 2015). Common disease symptoms in this type of disease include sunken, dead areas of bark, twig and/or branches, dieback, reduced foliage, yellow foliage, premature leaf drop (Jacobi, 2013). Infected trees do not die immediately as the process may extend over several years (Annesi et al., 2015). Some of the most common shoot, stem and trunk diseases include: (i) Nectria cankers (caused by Nectria spp.); (ii) Cytospora cankers (caused by various species in the genus of Cytospora) (Adams and Jacobi, 2016); (iii) Cryptodiaporthe (Dothichiza) canker (caused by Cryptodiaporthe populea); (iv) canker stain of plane tree (caused by Ceratocystis platani (C. fimbriata f.sp. platani)) (Luchi et al., 2013); (v) Dutch elm disease (caused by the fungal species Ophiostoma ulmi and O. novo-ulmi) (Ganley and Bulman, 2016); (vi) ash dieback (caused by Hymenoscyphus fraxineus-previously known as Chalara fraxinea and $H$. pseudoalbidus) (Pautasso et al., 2013; Kehr, 2016); (vii) Pine Pitch Canker (caused by Gibberella circinata with anamorphic state Fusarium circinatum) (Kehr, 2016). 


\section{(c) Root diseases}

Symptoms of most root diseases are expressed as slow or rapid decline of the tree, vigor loss and death of the tree which often begins from the upper branches due to the disturbance of water and nutrient uptake (Magasi, 1995). In urban environments tree roots are often significantly disturbed due to abiotic stresses (e.g soil compaction or inadequate room for root expansion, water stress) and they often become more vulnerable to attacks by root-rotting fungi (Magasi, 1995). Most of the fungi that infect tree roots move into the root and spread to other roots or up to the root collar, and they progressively (slowly or fast) weaken or kill the tree (Magasi, 1995). Some of the most common root-diseases include: (i) Phytophthora root rots (caused by Phytophthora spp.) (ii) Armillaria root rot (caused by several species which belong to the Armillaria genus) (Sanagorski et al., 2016); (iii) Ganoderma root rot (mainly caused by the fungi in the genus Ganoderma) (Lakatos et al., 2014).

\section{Discussion-further research}

This review shows that it is undoubtedly true that there are huge benefits deriving from urban forests and consequently their ecosystem services. It is a well-known fact that urban forests enhance the quality of life in an urban environment. What's more, their benefits mirror the sustainability of city life. More, specifically, ecosystem services have to do with air pollution removal, carbon sequestration and storage, energy saving, rainfall, interception, a decreased urban heat island effect and climate change adaptation. Based on the above we conclude that urban forests are important components of an ecosystem in every community development (Kim, 2016). As urban forests are composed of a mix of native and exotic tree species, they often have higher species diversity than the ones found in neighbouring native ecosystems. A city's image plus its quality of life is mostly determined by the health and appearance of the community's trees and generally its green spaces. On the one hand, high species diversity is useful minimizing ecosystem vulnerability to species-specific pests and disorders. On the other hand, we have to consider a certain risk to ecosystem health if the present exotic species are invasive plants posing various dangers to the native species (Wiseman and King, 2012).

Urban forest ecosystem assessments are a key tool to help quantify the benefits that urban forests provide, advancing our understanding of these valuable resources. It is clear that, urban forest and in particular a well-planned and managed urban forest with aim can provide many environmental, social and psychological benefits to human.

Current urban forest conditions must be fully studied so as to establish a good management concerning urban ecosystems. Tree maintenance, policy development and budgetary decisions depend on this understanding and on the assessments of urban forests. These assessments will greatly contribute to the awareness of changes and trends and their detection. Indicators of forest health or structure such as the number of plants, their location, species mix and age distribution must be closely monitored in order to achieve better results concerning the health of urban forests (Ciecko et al., 2012). It is remarkable that urban forests are threatened by changing climate, including spreading pests and diseases, changes to precipitation, and increased storm events. Therefore, the challenge faced by urban forest resource managers and planners is to balance the benefits, threatens and management costs that are associated with urban forests. Lack of information about the extent and magnitude of these benefits and the best approaches for providing them, often makes that task a very difficult one. Urban forestry plans should begin with consideration of the contribution that trees and forests can make to people's needs.

To sum up, further research is needed to fill the gap of empirical literature focusing on data concerning green areas on the optimal size, characteristics, distribution and influence on health effects (Bowler et al., 2010). Urban green infrastructure builds up soil carbon reserves contributing to carbon capture and less air pollution. Moreover, there is a need for a comprehensive and multifaceted approach to climate change vulnerability assessment and adaptation. Potential forest management-related effects include changes in forest health, regeneration success, growth and productivity, distribution and composition of species, forest structure, and age-class distribution. These effects, in turn, have implications for forest management goals, including biodiversity, ecosystem health, carbon, timber supply, non-timber goods and services, habitat, outdoor recreation, conservation, public safety, and social and cultural values (Halofsky et al., 2018). The existing gap in the research on green city areas should be covered as soon as possible, as biodiversity patterns interact with social and psychological benefits which may be associated with socioeconomic factors.

\section{Acknowledgements}

This research received no specific grant from any funding agency in the public, commercial, or not-for-profit sectors. We thank Hellenic Agricultural Organization "Demeter" and University of Thessaly for their bibliographic database and assistance.

\section{References}

Adams GC, Jacobi WR (2016). Cytospora canker of hardwoods. USDA Forest Service RMRS-General Technical Reports 335:9-93.

Akbar KF, Ashraf I, Shakoor S (2014). Analysis of urban forest structure, distribution and amenity value: a case study. The Journal of Animal and PlantSciences 24(6):1636-1642.

Angelstam P, Dönz-Breuss M (2004). Measuring forest biodiversity at the stand scale. An evaluation of indicators in European forest history gradients. Ecological Bulletins 51:305-332.

Annesi T, Calienno L, Picchio R, De Simone D, Lo Monaco A (2015). Degradation of some technological features in the wood of ornamental speciescaused by Inonotusrickii (Pat) Reid. Drewno 58(195):5-18.

Barnes I, Kirisits T, Akulov A, Chhetri DB, Wingfield BD, Bulgakov TS, Wingfield MJ (2008). New host and country records of the Dothistroma needle blight pathogens from Europe and Asia. Forest Pathology 38(3):178-195.

Beckerman J (2014). Leaf diseases of landscape trees and shrubs. Purdue 
Extension BP-143-W, Purdue University. Retrieved 2018 October 10 from https://www.extension.purdue.edu/extmedia/bp/bp-143-w.pdf.

Bowler D, Buyung-Ali L, Knight T, Pullin A (2010). A systematic review of evidence for the added benefits to health of exposure to natural environments. BMC Public Health 10(1):456.

Bolund P, Hunhammar S (1999). Ecosystem services in urban areas. Ecological Economics 29(2):293-301.

Botelho LLR, Cunha CCA, Macedo M (2011). O metodo da revisao integrativa nos estudos organizacionais. Gestao e Sociedade 5:121-136.

Chiesura A (2004). The role of urban parks for the sustainable city. Landscape and Urban Planning68(1):129-138.

Chiwa M, Kim DH, Sakugawa H (2003). Rainfall, stemflow, and throughfall chemistry at urban-and mountain-facing sites at MT, Gokurakuji, Hiroshima, Western Japan. Water, Air, and Soil Pollution 146(1-4):93-109.

Christopoulou O, Serafeim P, Minetos D (2007). Peri-urban and urban forests in Greece: Obstacle or advantage to urban development? Management of Environmental Quality: An International Journal 18(4):382-395.

Ciecko L, Tenneson K, Dilley J, Wolf K (2012). Seattle's forest ecosystem values analysis of the structure, function, and economic benefits. USDA Forest Service Pacific Northwest Research Station: Portland. Retrieved 2018 October 2 from https://www.fs.fed.us/pnw/research/gcra/ pdfs/FEVSeattlePublicReport-20120830-final.pdf.

Cohen P, Potchter O, Matzarakis A (2013). Human thermal perception of coastal Mediterranean outdoor urban environments. Applied Geography 37:1-10.

Colding J, Elmqvist T, Lundberg J, Ahrné K, Andersson E, Barthel S, ... Tengo M (2003). The Stockholm urban assessment (SUASweden). Millennium Ecosystem Assessment Sub-Global Summary Report, Stockholm.

Cornelis J, Hermy M (2004). Biodiversity relationships in urban and suburban parks in Flanders. Landscape and Urban Planning 69(4):385401.

Dimoudi A, Nikolopoulou M (2003). Vegetation in the urban environment: microclimatic analysis and benefits. Energy and Buildings 35(1):69-76.

Doick KJ, Peace A, Hutchings TR (2014). The role of one large greenspace in mitigating London's nocturnal urban heat island. Science of the Total Environment 493:662-671.

Fernandez-Juricic E (2004). Spatial and temporal analysis of the distribution of forest specialists in an urban-fragmented landscape (Madrid, Spain). Implications for local and regional bird conservation. Landscape and Urban Planning69(1):17-32.

Ferrini F, Fini A (2010). Sustainable management techniques for trees in the urban areas. Journal of Biodiversity and Ecological Sciences 1(1):1-20.

Fraedrich BR (2009). Recognition and treatment. Bartlett Tree Research Laboratories Technical Report.

Ganley RJ, Bulman LS (2016). Dutch elm disease in New Zealand: impacts from eradication and management programmes. Plant Pathology 65(7):1047-1055.

Georgi JN, Dimitriou D (2010). The contribution of urban green spaces to the improvement of environment in cities: Case study of Chania, Greece. Building and Environment 45(6):1401-1414.
Gustafsson L (2002). Presence and abundance of Red-listed plant species in Swedish forests. Conservation Biology 16(2):377-388.

Haines-Young RH, Potschin M (2008). England's terrestrial ecosystem services and the rationale for an Ecosystem Approach. Project NR0107. Retrieved 2018 October 13 from http://www.nottingham.ac.uk/ cem/pdf/NR107_FTR_080108.pdf.

Halofsky JE, Andrews-Key SA, Edwards JE, Johnston MH, Nelson HW, Peterson DL, ... Williamson TB (2018). Adapting forest management to climate change: The state of science and applications in Canada and the United States. ForestEcology and Management 421:8497.

Hansmann R, Whitehead I, Krajter Ostoić S, Živojinović I, Stojanovska M, ... Barstad J (2016). Partnerships for urban forestry and green infrastructure delivering services to people and the environment: a review on what they are and aim to achieve. South-East European Forestry7(1):9-19.

Himelick EB (1997). Disease stresses of urban trees. Weeds Trees \& Turf, Gen. Tech.pp 113-125.

Jacobi WR (2013). Honeylocust diseases. Gardening Series, Diseases. ColoradoState University Extension.

Jansson M (2014). Green space in compact cities: the benefits and values of urban ecosystem services in planning. The Nordic Journal of Architectural Research 26(2):139-160.

Jose GVH, Karina P, Patricia H (2018). Urban green spaces as a component of an ecosystem functions, services, users, community involvement, initiatives and actions. International Journal of Environmental Sciences and Natural Resources 8(1):555-730.

Kabisch N, Qureshi S, Haase D (2015). Human-environment interactions in urban green space. A systematic review of contemporary issues and prospects for future research. Environmental Impact Assessment Review 50:25-34.

Kehr R (2016). Aspects of urban tree pathology. In: Roloff A (Ed). Urban Tree Management for the Sustainable Development of Green Cities. Chichester, Wiley-Blackwell pp 58-77.

Kim G (2016). Assessing urban forest structure, ecosystem services, and economic benefits on vacant land. Sustainability 8(7):679.

Konijnendijk C, Annerstedt M, Maruthaveeran S, Nielsen A (2013). Benefits of urban parks: a systematic review. A report for IFPRA. Ifpra. Retrieved 2018 October 3 from http://wwwifpra.org/images/ parkbenefits.pdf.

Konijnendijk CC (2003). A decade of urban forestry in Europe. Forest Policy andEconomics 5(3):173-186.

LakatosF, MirtchevS, Mehemeti A (2014). Hand book of major forest pests in Southeast Europe. Food and Agriculture Organization of the United Nations, Pristina pp 71-100.

Luchi N, Ghelardini L, Belbahri L, Quartier M, Santinia A (2013). Rapid detection of ceratocystis platani inoculum by quantitative real-time PCR assay. Applied and Environmental Microbiology 79(17):5394-5404.

Magasi LP (1995). Insects and diseases of the urban forest in the Maritimes. Journal of Arboriculture 21:21-24.

MEA (2005). MEA - Millennium Ecosystem Assessment: Ecosystems and Human Well-being: Synthesis. Island Press, Washington, D.C.

Michopoulos P, Baloutsos G, Economou A, Samara C, Thomaidis NS, Grigoratos Th (2007). Nutrient cycling and status in an urban pine forest in Athens, Greece. Plant and Soil 294(1):31-39. 
16

Molla M (2015). The value of urban green infrastructure and its environmental response in urban ecosystem: A literature review. International Journal of Environmental Sciences 4(2):89-101.

Mörtberg U, Wallentinus HG (2000). Red-listed forest bird species in an urban environment - assessment of green space corridors. Landscape and Urban Planning 50(4):215-226.

Nowak DJ (1994). Air pollution removal by Chicago's urban forest. In: McPherson EG, Nowak DJ, Rowntree RA (Eds). Chicago's Urban Forest Ecosystem: Results of the Chicago Urban Forest Climate Project. USDA Forest Service General Technical Report NE-186, Radnor, PA pp 63-81.

Nowak D, Greenfield E, Hoehn R, Lapoint E (2013). Carbon storage and sequestration by trees in urban and community areas of the United States. Environmental Pollution 178:229-236.

O’Brien L, De Vreese R, Kern M, Sievänen T, Stojanova B, Atmis E (2017). Cultural ecosystem benefits of urban and peri-urban green infrastructure across different European countries. Urban Forestry and Urban Greening 24:236-248.

Olsen MW (1999). Diseases of urban plants in Arizona. Corporative Extension, College of Agriculture and Life Sciences, University of Arizona, Tucson, Arizona pp 1-28.

Paap T, Burgess TI, Wingfield MJ (2017). Urban trees: bridge-heads for forest pest invasions and sentinels for early detection. Biological Invasions 19(12):3515-3526.

Patarkalashvili TK (2017). Urban forests and green spaces of Tbilisi and ecological problems of the city. Annals of Agrarian Science 15(2):187191.

Pautasso M, Aas G, Queloz V, Holdenrieder O (2013). European ash (Fraxinus excelsior) dieback - A conservation biology challenge. Biological Conservation 158:37-49.

Phillips DH, Burdekin DA (1982). Diseases of forest and ornamental trees. The Macmillan Press Ltd, London, United Kingdom pp 435.

Plexida S, Solomou A, Papadouli K (2014). Benefits of urban green spaces in aMediterranean city.LAP LAMBERT Academic Publishing pp 1-53.

Rosenzweig C, Solecki W, Romero-Lankao P, Mehrotra S, Dhakal S, Bowman T, Ibrahim S (2018). Climate Change and Cities: Second Assessment Report of the Urban Climate Change Research Network. In: Rosenzweig C, Solecki W, Romero-Lankao P, Mehrotra S, Dhakal S, Ali Ibrahim S (Eds). Climate Change and Cities: Second Assessment Report of the Urban Climate Change Research Network. Cambridge University Press, Cambridge.

Rosenzweig C, Solecki WD, Hammer SA, Mehrohtra S (2011). Climate change and cities: first assessment report of the urban climate change research network. Cambridge University Press, Cambridge pp 312.

Rowe DB (2011). Green roofs as a means of pollution abatement. Environmental Pollution 159(8-9):2100-2110.

RoyS, ByrneJ, PickeringC (2012). A systematic quantitative review of urban tree benefits, costs, and assessment methods across cities in different climatic zones. Urban Forestry and Urban Greening 11(4):351-363.
Rupprecht CDD, Byrne JA (2014). Informal urban greenspace: a typology and trilingual systematic review of its role for urban residents and trends in the literature. Urban Forestry and Urban Greening 13(4):597-611.

Sæbø A, Janhall S, GawronskiSW,Hanslin HM (2017). Urban forestry and pollution mitigation. In: Ferrini F, Konijnendijk van den Bosch C, Fini A (Eds). Routledge Handbook of Urban Forestry. Abingdon, UK, Routledge.

Sanagorski L, Trulock A, Smith J (2016). Armillaria Root Rot (also known as Mushroom Root Rot, Shoestring Root Rot, Honey Mushroom Rot). Environmental Horticulture Department, UF/IFAS Extension, University of Florida, ENH1217 pp 1-5.

Solomou AD, Papadouli K, Plexida S, Kostopoulos A, Akrivou E (2014). Promoting and preserving biodiversity in urban green spaces in a city of central Greece.EFUF, 3-7 June2014, Lausanne, Switzerland pp 137.

Sturrock RN, Frankel SJ, Brown AV, Hennon PE, Kliejunas JT, Lewis KJ, Worral JJ, Woods AJ (2011). Climate change and forest diseases. Plant Pathology 60:133-149.

Tainter FH, Baker FA (1996). Principles of forest pathology. John Wiley and Sons, New Yorkpp 832.

Tallis H, Polasky S (2009). Mapping and valuing ecosystem services as an approach for conservation and natural resources management. The Year in Ecology and Conservation Biology: Annals of the New York Academy of Science 1162:265-283.

TattarTA (1989). Diseases of shade trees. Academic Press pp 1-391.

Tomlinson I, Potter C, Bayliss H (2015). Managing tree pests and diseases in urban settings: the case of Oak Processionary Moth in London, 20062012. Urban Forestry and Urban Greening 14(2):286-292.

UN-Habitat (2011). Cities and climate change: global report on human settlements, United Nations Human Settlements 2011. Programme, Earthscan,London pp 300.

Wolf KL (2010). Active living - A literature review. In: Green Cities: Good Health. College of the Environment, University of Washington.

Wiseman E, King J (2012). i-Tree ecosystem analysis Roanoke. College of Natural Resources and Environment: Blacksburg, VA, USA pp 27.

Woods AJ, Martín-García J, Bulman L, Vasconcelos MW, Boberg J, La Porta N,DiezJ (2016). Dothistroma needle blight, weather and possible climatic triggers for the disease's recent emergence. Forest Pathology 46(5):443-452.

Word Cloud (2018). Word Cloud. Retrieved 2018 November 3 from https://www.wordclouds.com/.

Ziller WG, Hunt RS (1977). Lophodermium needle cast of pines in nurseries and plantations. Forestry Canada, Forest Insect and Disease Survey, Forest Pest pp 14.

Zoeller RF (2009). Lifestyle in the prevention and management of cancer: physical activity. American Journal of Lifestyle Medicine 3(5):353-361. 